\title{
MODEL OF COOPERATION IN THE NETWORK OF NON-ENTERPRISE ORGANIZATIONS ON THE EXAMPLE OF REGIONAL TOURISM ORGANIZATIONS IN POLAND
}

\author{
WOJCIECH FEDYK, ${ }^{1}$ MIECZYSŁAW MORAWSKI, ${ }^{2}$ URSZULA \\ BĄKOWSKA-MORAWSKA, ${ }^{3}$ FRANTIŠEK LANGER, ${ }^{4}$ SOŇA JANDOVÁ ${ }^{5}$
}

\author{
1 University School of Physical Education, Wrocław \\ e-mail: wojciech.fedyk@awf.wroc.pl \\ 2 University of Economics, Wrocław \\ e-mail:mieczyslaw.morawski@ue.wroc.pl \\ 3 University of Economics, Wrocław \\ e-mail: urszula.bakowska-morawska@ue.wroc.pl \\ 4 Masaryk University, Brno \\ e-mail: 26266@mail.muni.cz \\ 5 Technical University of Liberec \\ e-mail: sona.jandova@tul.cz
}

\section{JEL CODES}

KEYWORDS

ABSTRACT

\section{Z3, L3, L83}

regional tourism organizations, effectiveness, cooperation models, promotion management

In the authors' opinion, one should look for a new mission for regional tourism organizations in Poland (RTOs), in the face of radical changes in tourism and their high level of organizational maturity. Therefore, our research problem is to identify and settle which model of functioning (cooperation) of RTOs is adequate to their internal and external conditionings, as well as their inherent features - which model would allow them to function effectively. The aim of the paper is to formulate a proposal of a new functional model of RTOs based on networking and cooperation with their stakeholders. The paper includes a coherent and versatile collection of qualitative and quantitative research methods, including a multi-dimensional, innovative questionnaire and multistage method of assessment of RTOs' effectiveness.

The authors are determining and estimating a catalogue of features influencing the level of effectiveness of functioning of RTOs; the features describe the character of cooperation between the organization and its environment. In spite of disclosed divergence of ideas on the directions and purposefulness of modification of the existing RTO system, the authors propose an evolutionary system of RTO functioning as a networking organization, indicating the features, actions and tasks that will implement the new model to organizational practice. In consequence this will lead to the increase of effectiveness of the organization and eventually result in changes in the logistics and quality of management of tourist promotion of a region.

In the opinion of authors, the proposed method of measuring the effectiveness of RTO network cooperation with its stakeholders should be implemented to the assessment of effectiveness of other tourism management and promotion organizations. 


\section{Introduction}

The present stadium of development of tourism, broadly understood as the service sector, form of economic activity or model of business, needs dynamic as well as radical changes. It results from many parallel issues: growing turbulence of natural, social and other factors, taking place in tourist destinations, growing competition between tourist enterprises, changing needs and expectations of the clients towards the level of service, expected benefits, etc.

The complexity, intensity and unpredictability of various trends on the tourist market is inducing the creation of modern, technologically advanced and highly distinctive tourist products. This process makes it necessary for the companies and organizations that are responsible for the development of tourism (on the infrastructural, legal or conceptual level) to cooperate in various forms. One could assume that at present no tourist product has got a monolithic structure, being prepared, promoted and commercialized entirely by a single operator. It is especially visible from the perspective of the tourist chain of value (Morawski, 2012, p. 50). Within the tourist economy a necessary complementation of a typical "tourist chain of value" - which is an example of intensive and multidirectional cooperation in itself (Weiermair, 1997, p. 40) - are various support organizations: educational, informative, initiating, counseling and other. Regional Tourism Organizations (RTOs) are undoubtedly amongst them. They are both a subject and an object of analysis in this paper.

Regional Tourism Organizations, which at present operate in all 16 provinces of Poland, were created in the 2000-2006 period (Act of June 25..., 1999), becoming an important element of a threestep system of management of promotion of tourism in Poland, the other two being Polish Tourism Organization (PTO) and Local Tourism Organizations (LTO) (Wąsowicz-Zaborek, 2009).

Several years of functioning of 16 RTOs calls for a deepened reflection on the validity of their functioning within the framework of managing national tourism and its promotion. The idea behind the creation of these organizations was the need to create a solid, institutional support for the rapidly developing tourist market.

During their 18 years of functioning the RTOs, which bring together over 1400 members, have financial means of PLN 46 million and employ around 130 people, have become an essential element of Polish tourism system (Gołembski, Niezgoda, 2014), and even earned themselves the name of the "regional leader" (Rapacz, Jaremen, 2007; Zmyślony, 2014; Żemła, 2010) and "the instrument of regional tourism policy" (Borzyszkowski, 2011a, 2011b, Panasiuk, 2009).

Thus, the RTOs reached a certain maturity as an organization, which calls for a natural need for a change, in the pursuit for "organizational perfection" (Waterman, Peters 1986). This implies the need for continuous periodic assessment of the character of this change, including identification of its factors and determinants and their effectiveness.

The set of determinants of effectiveness of RTOs functioning comprises of external and internal elements. The internal ones are: decrease in professional competence, increased knowledge of the tourism sector, problems, challenges and perspectives, integrated teams of employees and even the well-known brand of the institution, and many others. The external determinants are: 
increasing pressure from competition, expectations of the surrounding businesses, expectations of an intelligent, well-informed client - traveler and other.

The effectiveness of an organization is hard to define unequivocally, which is a result of too many definitions, interpretations and approaches to it (Kowal, 2013). It's also hard to measure because of the influence of many varied factors (Sobolewski, 1998; Stabryła, 2011; Zieleniewski, 1972; Ziębicki, 2012), including sheer luck (Bratnicki, 2009).

At the same time, there were only a few attempts at making outlines (not models) of assessment of effectiveness (Migdal, 2008), and isolated attempts at assessing the effectiveness of RTO functioning (Opracowanie metody..., 2008) or at ranking them, ${ }^{1}$ which caused a lot of controversies because of the methods used; they cannot be considered as standardized and scientific classifications of assessment of RTOs' functioning.

\section{Research methods}

The choice of research methods as well as the scope of research on the functioning of RTOs was the authors' own conception and was meant to show the conditions for the functioning of RTOs as well as the idea for the management of tourism and its promotion in the regional system within the frames of multidirectional cooperation and competition.

The research methods included desk research as well as direct and indirect data analysis (original documents of individual RTOs: rules, regulations, plans, statutes, annual reports, data from websites). The authors did a survey of scientific writings concerning analyses of RTO functioning as well as models of functioning of these organizations in managing tourist regions. Moreover, the authors referred to their own research of determinants of RTO functioning and level of their effectiveness (more: Fedyk, 2016; Fedyk, Morawski, 2014, 2016).

For drawing conclusions, the following methods were used: deductive reasoning method, comparative analysis including the technique of description of similarities and dissimilarities, and - to simplify the presentation of issues - method of reduction and techniques of authors' own observation.

The research included all 16 Polish RTOs, and the questionnaires were carried out on the basis of aforementioned authors' own questionnaire. The aim of the diagnosis was the evaluation of effectiveness of implementation of RTO functioning model (RTOs are seen here as network cooperation organizations) from the point of view of their strategic partners (understood as subjects of intentional surrounding, following R. W. Griffin [2004], with deliberate choice of strategic respondents and with the usage of adapted five-level Likert's scale) with simultaneous usage of some elements of researching the relations of an organization with its surroundings, proposed by J. Olearnik (2009, pp. 49-87). Deliberate choice of respondents included analysis of quality

1 The analysis was carried out in the 2009-2011 period by the editorial staff of trade periodical "Rynek Podróży" based on several variables concerning RTOs, for example number of members and its growth, amount of membership fees, budget, number of organized tourist fairs, number of printed promotional materials, number of web pages and their rating, number of organized events, etc. 
structure of RTO members, allowing for selection of dominant and recurrent types of partners. Altogether, there were 15 types of selected partners that prevailed in all 16 RTOs. These were: a) from the common RTO members: self-government of a given voivodship (department of tourism), district (community), local tourism organizations (LTOs), local activity group (LAG), tourist associations, tourist chamber, local tour operator, university and other (distinctive of a given RTO); b) from the non-members, cooperating with RTOs: local tourism organizations, local activity groups, various tourist entrepreneurs (more: Fedyk, 2016).

Deepened interviews with the usage of CATI method were carried out with the managers of all 16 RTOs. At the same time a pilot study was carried out, directed at 15 experts from RTOs and their surroundings (including members of the Ministry of Sport and Tourism, Polish Tourism Organization, RTO forum and independent experts). Proper research, relating to a number of variables and features of RTO functioning as a network cooperation, was eventually carried out with 137 respondents, representing varied subjects from all 16 RTOs, which made up $42.81 \%$ of the assumed research sample (320 questionnaires). The proper research concerned the assessment of four groups of criteria and indicators (197 variables) of RTO effectiveness, that is effectiveness of statutory aims (51 variables) and economic aims (30 variables), benefits of cooperating entities (56 variables) and general features of RTOs effectiveness (60 variables) (more: Fedyk, 2016).

Based on aggregated questionnaire data, and using the Grapher programme, 32 standards (graphs) were created - profiles of organizational effectiveness of RTOs with the reference to: statutory and economic aims, gains achieved by its regular members, and general features of effectiveness of their functioning together with authors' own determination of "effectiveness thresholds", indicated in the aforementioned graphs (more: Fedyk, 2016).

According to analogous rule, the authors also created 4 types of profiles of RTO effectiveness for 8 selected RTOs, taking into consideration their position in the classification (see: Fedyk, 2016) and the number of questionnaires received from the respondents of a given RTO (more than 50\% of the audited population of a given RTO). The graphs contained also profiles of organizational effectiveness of RTOs with the reference to 4 indicated groups of variables basing on results of research poll of experts.

The comparison of "expert models" (effectiveness profiles) and the "reality" described by the RTO partners during empirical study, showed differences, variations, regularities and irregularities, and allowed for distinguishing certain features that increased or decreased the effectiveness of RTOs (here - "effectiveness thresholds") and indicated the desirable directions of changes of RTO functioning.

\section{Discussion}

In modern world tourism is a network of interrelated actions and services of tourism economy entities (hotels, restaurants, transportation companies, shop owners, tourist attractions, managing entities, etc.), and many other factors. 
The main goal in establishing cooperation within network systems is to achieve synergy. A visible exposition of this postulate is the tourist sector. We are dealing here with a huge dispersion of many companies and institutions, which are most often specialized operators of various services, often specific or niche due to the type of customer, type of service, area of operation. However, creating a comprehensive offer and its promotion, the benefits package that fully fills the leisure time of a tourist is virtually impossible by a single company. In such an environment, the role of RTOs as an integrator of the offer, an expert offering marketing support (segment analysis, promotion, commercialization, legal) seems obvious.

In this aspect of tourism sphere, the phenomena that are constantly present are, on the one hand: increasing competitiveness (both specific tourist destinations, tourist reception areas and individual service providers compete), and on the other the nature (model) of cooperation between all entities in the tourism sector.

It should be noted that the weakness of the Polish tourism economy is the noticeable lack of cooperation between tourism enterprises, and what is more important, low level of cooperation between enterprises and tourism organizations (here - RTO), and the key threat to tourism are the insufficient system changes in management of tourism in Poland (Zmyślony, 2013).

The conditioning factor for the success of Polish tourism is deepening cooperation between enterprises, tourist industry institutions and the field of science, and the implementation of modern tourism management systems with the help of RTOs, and this thesis is confirmed by the results of existing research and diagnostic survey (Fedyk, 2016; Fedyk, Morawski, 2014, 2016).

It is legitimate to indicate that the creation of integrated tourism development networks, including various entities involved in the competitiveness of the tourism economy (entrepreneurs, business and science institutions, financial institutions, NGOs - such as RTO), affects the formation of strong cross-sectoral tourism links and increases the strength of the economic impact of this sector. At the same time, the location and operation of RTOs at the interface between supply and demand in the tourism economy (fig. 1) cause, or even force the need to build new types and forms of cooperative relations between the organization and its closer and wider environment (Dębski, 2012a, 2012b; Grabińska, Mierniczak 2010; Migdal, 2008, Wanagos, 2011, Walas, 2007).

Regional tourism organizations are no longer "beginner organizations" in the sphere of regional or national tourism, because some of them have already gone beyond the formal role of the implementer of basic tasks (canon) written in the Act on PTO (i.e. promotion or tourist information). Often RTOs take on the role of a strong partner (but not always also a direct implementer) for the industry, public institutions, NGOs and other tourism organizations in the region undertaking new tasks in the area of initiating the development of various forms of tourism or pointing to opportunities and areas of joint activities for the tourist economy. Some RTOs while aiming at increasing their competences and using niche skills (including the potential of their cadres: director, employees, board members), seek to gain the status of a leader of tourism development in the region through, inter alia, strategic management and impact on entities and institutions not only from the sphere of tourism and through involvement in issues only indirectly related to tourism (including environmental protection, investment consulting, science and research). 
All of these phenomena trigger the need for a firm correction in the RTO functioning model. These activities are also necessary in the light of the ambiguity of the rules of operation and various ways and levels of RTOs' effectiveness, which was indicated by the analyses (more: Fedyk, 2016; Fedyk, Morawski, 2016), which features badly influence or destabilize the whole system's evolution.

Evolutionally shaping of different solutions (current models of the effectiveness of functioning), adopted in individual RTOs can perpetuate bad patterns of action, since there have never been universal recommendations based on "good examples" for the model of operation of all ROTs ${ }^{2}$ and strong disproportions in the effectiveness of their actions are noticeable (Fedyk, 2016). This implies the need to take the effort to change the current model of RTOs' functioning as a condition for their further development, and, in some cases, their further existence.

\section{Results of the research}

Comparing the levels of effectiveness of regional tourism organizations, let alone ranking or classifying them, is a multidimensional process and one that is very strongly dependent on local conditions of functioning of a given RTO in the region (cf. Fedyk, 2016; Fedyk, Morawski 2014, 2016; Fedyk, Kachniewska, 2016; Fedyk, Meyer, Potocki, 2016). At the same time, the opportunity to make an attempt to compare the level of effectiveness and cooperation with the environment realized by individual RTOs is recognized by comparing the results of the analysis of performance thresholds in terms of the effective level of statutory and economic objectives and the level of benefits obtained by members and stakeholders of these organizations, and the level of performance characteristics considered to affect the overall effectiveness of the organization (its maintenance or growth). Due to the limitations of the size of the article, there were no presented profiles of the effectiveness of achieving goals by RTOs, but merely aggregated conclusions (more: Fedyk, 2016).

As a result of the conducted questionnaire, a qualitative catalog of the functioning characteristics of all RTOs was identified, ${ }^{3}$ which ensure the current effectiveness of their operation and / or may affect the increase of this effectiveness in relation to particular groups of studied characteristics.

In the group of variables examined (tab. 1), referring to the level of effectiveness of the implementation of statutory aims of RTOs concerning network cooperation, the following have been noticed:

- high efficiency of RTOs in relation to the implementation of the majority of objectives in the area of building a cooperation network with the environment, and at the same time perceived phenomenon (which requires intervention and change) is less effective organization

2 With the exception for the postulates indicated in Kodeks Dobrych Praktyk... (see: Wąsowicz-Zaborek, 2009).

3 W. Fedyk (2016) identifies a total of 68 exo- and endogenous conditions affecting the effectiveness of RTOs functioning and indicates, on the basis of surveys of RTO stakeholders, 197 characteristics affecting the level of their effectiveness. 


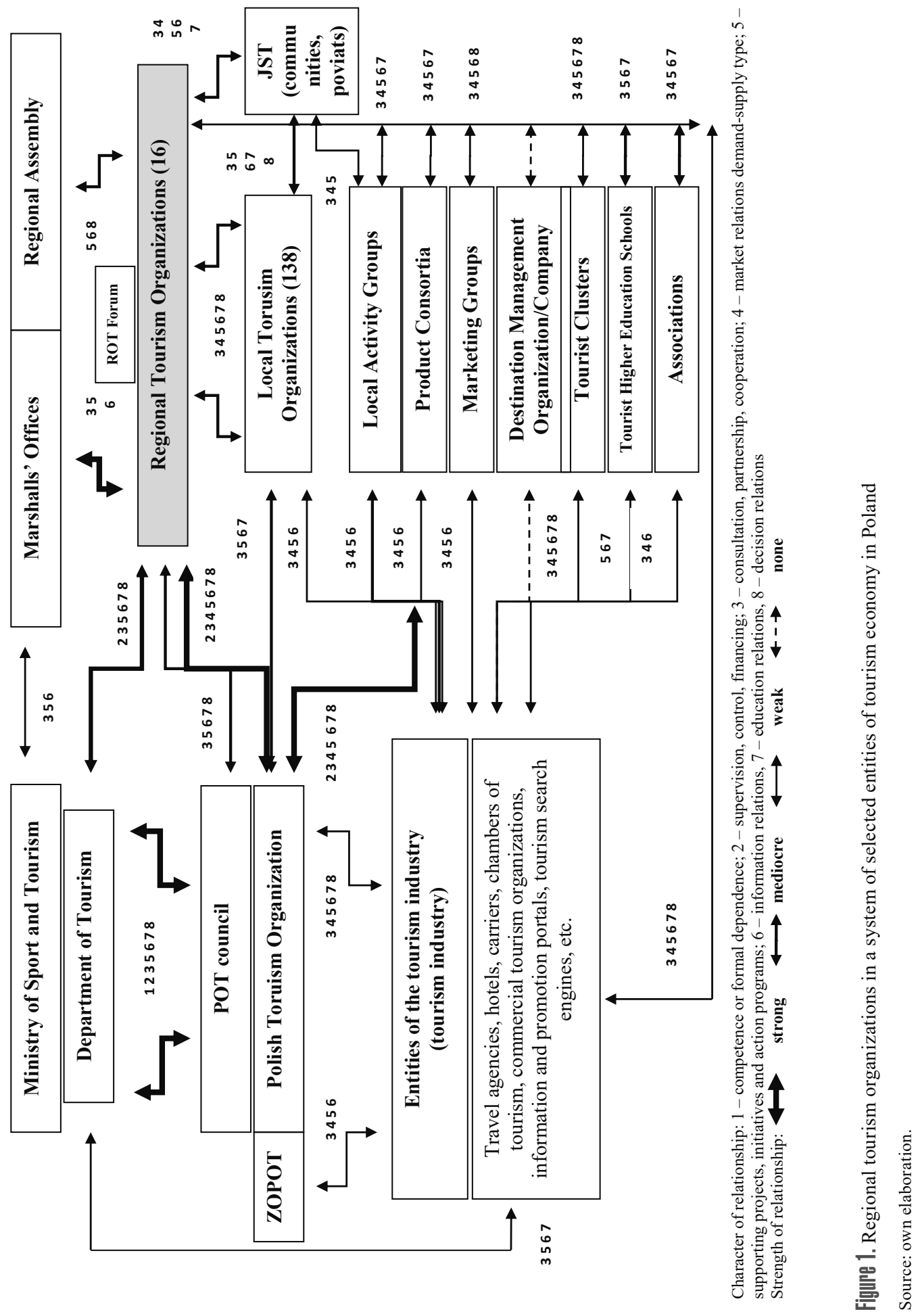


in cooperation with LTOs, which should be a strategic partner of RTO within the existing model of cooperation in the tourism promotion of the PTO-RTO-LTO Polish system,

- a worrying phenomenon is the limited degree of RTOs' effectiveness in activities supporting entrepreneurship and economic development, and in creating conditions for organization members to build a platform for cooperation of tourist business entities with the authorities in the region and the country,

- in view of the new types of statutory objectives proposed by the authors in the area of building a network of cooperation with the environment, RTO stakeholders clearly indicated the importance of these features (after implementation to organizational practice) for raising the level of RTOs effectiveness, including:

- key significance of activities related to joint strategic planning, development of the organization's communication system with the environment and strengthening of ties and trust relationships with members,

- big importance of expanding the in-house support system for members (members' rights list) and increasing the awareness of the social responsibility of entrepreneurs members of the organization,

- the need to strengthen the mechanisms for sharing experience, knowledge, actual defining of common goals of action or getting entrepreneurs to cooperate,

- the organization's stakeholders perceive the effectiveness of the organization's activities and the need to achieve the objectives aiming at building the position of RTO as the leader in the system of network cooperation with the environment.

- The results of the conducted research indicate that in the opinion of stakeholders only 13 types of statutory goals of regional tourism organizations are achieved at the level of the determined effectiveness threshold (25.49\% of the total number of 51 goals), and only 9 goals are achieved at the high effectiveness threshold level (17.64\%).

- The diagnosis of the above-mentioned level of effectiveness of achieving statutory objectives (in the field of network cooperation) by RTOs is in several types of target groups coincident with the indications of experts participating in the survey, while reserving a more critical assessment of the level of effectiveness obtained, especially with regard to:

- problems in the sphere of building a network of cooperation with the environment, including perceived lack of expected effectiveness in creating multidimensional platforms of cooperation with entrepreneurs,

- ineffectiveness of RTOs in achieving objectives regarding:

- projects implemented in the formula of project teams with the participation of stakeholders of the organization,

- building new forms of cooperation in the form of product consortia or tourist clusters,

- acting as a leader in the system of cooperation with the environment.

In the light of the above analysis, the correction and creation of a transparent, clearly expressed hierarchical ladder of statutory objectives of regional tourism organizations, including the creation of a separate catalog of strategic goals (official objectives) broadly presenting publicly 
the intentions and directions, is justified and necessary to increase the effectiveness of RTOs. Undertaken actions and a catalog of operational goals (actual intentions of the organization) relate to the expectations of members and organization's stakeholders, including strengthening RTO activities in the area of entrepreneurship and relations with tourism industry entities (also in new organizational forms: tourist clusters, product consortia, Destination Management Company), as well as the overall economic efficiency of the tourism sector in the region.

Due to regional conditions of RTOs' functioning, the authors of the study call for unification of the new structure of strategic goals for all RTOs, while maintaining individual models of the structure of operational objectives in individual organizations adapted to regional conditions and the organization's environment.

Table 1. Effectiveness of the implementation of statutory objectives (concerning network cooperation) by regional tourism organizations according to the opinion of stakeholders

\begin{tabular}{|c|c|c|c|c|c|c|}
\hline \multirow{4}{*}{$\begin{array}{l}\text { Identified goals of regional tourism organizations (statutory } \\
\text { approach) }\end{array}$} & \multicolumn{6}{|c|}{$\begin{array}{c}\text { Evaluation of the effectiveness of statutory objectives implementation by } \\
\text { regional tourism organizations }\end{array}$} \\
\hline & \multicolumn{6}{|c|}{$\begin{array}{c}0 \text { - resignation, } 1 \text { - lack of effectiveness, } 2 \text { - low efficiency, } \\
3 \text { - I have no opinion as to the level of effectiveness, } \\
4 \text { - actions are effective, } 5 \text { - high efficiency }\end{array}$} \\
\hline & 0 & 1 & 2 & 3 & 4 & 5 \\
\hline & \multicolumn{6}{|c|}{$\%$ of responses given by respondents } \\
\hline \multicolumn{7}{|l|}{$\begin{array}{l}\text { The area of goals in the sphere of building cooperation } \\
\text { networks with the environment (objectives noted in the } \\
\text { statutes) }\end{array}$} \\
\hline $\begin{array}{l}\text { Integrating institutions and communities interested in the } \\
\text { tourist development of the region }\end{array}$ & 0.00 & 4.38 & 11.68 & 11.68 & 16.06 & 54.74 \\
\hline Support for local organizations and tourist structures & 0.73 & 3.65 & 10.22 & 10.22 & 18.25 & 51.82 \\
\hline Creating partnerships for regional development & 0.00 & 6.57 & 16.06 & 16.06 & 13.87 & 51.09 \\
\hline Cooperation with LTO & 0.00 & 1.46 & 9.49 & 9.49 & 19.71 & 44.53 \\
\hline $\begin{array}{l}\text { Running business supporting economic development } \\
\text { (entrepreneurship, supporting communities and local } \\
\text { communities) }\end{array}$ & 0.73 & 6.57 & 23.36 & 23.36 & 41.61 & 23.36 \\
\hline $\begin{array}{l}\text { Creating a platform for cooperation of tourist business entities } \\
\text { with the authorities }\end{array}$ & 0.00 & 8.03 & 15.33 & 15.33 & 27.74 & 38.69 \\
\hline \multicolumn{7}{|l|}{$\begin{array}{l}\text { The area of goals in the sphere of building a network } \\
\text { of cooperation with the environment (goals postulated by } \\
\text { the authors) }\end{array}$} \\
\hline $\begin{array}{l}\text { Joint creation and implementation of development strategies } \\
\text { and tourist promotion programs }\end{array}$ & 0.73 & 5.11 & 9.49 & 9.49 & 18.25 & 56.20 \\
\hline $\begin{array}{l}\text { Initiating and developing cooperation by creating an active } \\
\text { communication system with the environment }\end{array}$ & 0.00 & 4.38 & 10.95 & 10.95 & 13.87 & 50.36 \\
\hline Building a trust relationship with members & 0.73 & 4.38 & 4.38 & 4.38 & 26.28 & 45.26 \\
\hline $\begin{array}{l}\text { Permanent extension of the support system (substantive, } \\
\text { organizational, financial) for members (,rights card”) }\end{array}$ & 0.73 & 12.41 & 10.95 & 10.95 & 45.26 & 22.63 \\
\hline $\begin{array}{l}\text { Taking actions for the development of the concept } \\
\text { of corporate social responsibility (CRS) }\end{array}$ & 5.11 & 13.14 & 15.33 & 15.33 & 44.53 & 18.98 \\
\hline Initiating and creating tourist cluster structures & 3.65 & 10.22 & 16.06 & 16.06 & 43.07 & 20.44 \\
\hline $\begin{array}{l}\text { Creating real mechanisms of joint determination of the } \\
\text { organization's goals by members }\end{array}$ & 0.73 & 6.57 & 12.41 & 12.41 & 28.47 & 41.61 \\
\hline Initiating and creating product consortia in tourism & 2.19 & 5.84 & 18.25 & 18.25 & 39.42 & 28.47 \\
\hline $\begin{array}{l}\text { Acting as a leader in a network collaboration with the } \\
\text { environment (clusters, network broker, tourism animator) }\end{array}$ & 0.73 & 8.03 & 13.87 & 13.87 & 38.69 & 32.85 \\
\hline
\end{tabular}




\begin{tabular}{|c|c|c|c|c|c|c|}
\hline \multirow{4}{*}{$\begin{array}{l}\text { Identified goals of regional tourism organizations (statutory } \\
\text { approach) }\end{array}$} & \multicolumn{6}{|c|}{$\begin{array}{l}\text { Evaluation of the effectiveness of statutory objectives implementation by } \\
\text { regional tourism organizations }\end{array}$} \\
\hline & \multicolumn{6}{|c|}{$\begin{array}{c}0 \text { - resignation, } 1 \text { - lack of effectiveness, } 2 \text { - low efficiency, } \\
3 \text { - I have no opinion as to the level of effectiveness, } \\
4 \text { - actions are effective, } 5 \text { - high efficiency }\end{array}$} \\
\hline & 0 & 1 & 2 & 3 & 4 & 5 \\
\hline & \multicolumn{6}{|c|}{$\%$ of responses given by respondents } \\
\hline $\begin{array}{l}\text { Creating membership mechanisms that allow entities from } \\
\text { outside tourism to be involved in the organization }\end{array}$ & 2.92 & 11.68 & 15.33 & 15.33 & 37.96 & 27.01 \\
\hline $\begin{array}{l}\text { Creating and developing mechanisms for the exchange } \\
\text { of experience in the undertaken activities }\end{array}$ & 1.46 & 6.57 & 15.33 & 15.33 & 33.58 & 36.50 \\
\hline $\begin{array}{l}\text { Creating real mechanisms for jointly defining the goals of the } \\
\text { organization's activities with entities from the environment }\end{array}$ & 0.73 & 9.49 & 13.87 & 13.87 & 34.31 & 33.58 \\
\hline $\begin{array}{l}\text { Creating and developing project teams appointed from } \\
\text { members of various organizations }\end{array}$ & 1.46 & 8.76 & 18.25 & 18.25 & 31.39 & 34.31 \\
\hline
\end{tabular}

Source: own study based on surveys.

In the group of the examined variables (tab. 2) referring to the level of effectiveness of the action from the perspective of the benefits gained by the stakeholders while cooperating with RTO, one should notice and record:

- in relation to all types of benefits identified by the authors, the majority of respondents (between $56.93 \%$ and $79.56 \%$ of respondents) pointed to their achievement thanks to cooperation with RTO in an effective (I achieve benefits) and highly effective (I achieve great benefits) level,

- high level of obtained benefits in the sphere of organization and management of tourism, with particular emphasis by stakeholders on:

- the possibility of exchanging experiences in the undertaken activity,

- voluntary cooperation and the autonomy of members, not limited by the formula of affiliation to an organization (freedom of joining, leaving an organization) while maintaining economic and legal independence of partners (equal passive and active rights),

- building a relationship of trust with members of the organizations interested in offering the member their own services,

- in the group of benefits of financial nature, the stakeholders emphasize achieving large benefits from cooperation, in particular in the area of easier access and more effective acquisition of funds from the EU budget and implementation (co-financing) of joint projects,

- the majority of stakeholders strongly point to achieving large benefits from cooperation with RTOs in the area of tourism product development, which is directly related to the strategic goals and tasks of the organization. At the same time, the worrying phenomenon is lower level of obtained benefits in the area of creation and promotion of tourist products using the network cooperation formula of the organization members (joint concepts, obtaining subsidies and implementation), which indicates the need for modification of tasks and activities undertaken in RTOs and the model (principles) of cooperation with its members,

- RTO stakeholders effectively gain great benefits in the field of pro-tourism education (jointly organized training, participation in specialist training), and at the same time indicate 
gaining smaller benefits relating to the flow and diffusion of expertise between entities in the organization or access to know-how (innovation) and specialist data and analyzes, which raises concerns about the need to base modern tourism economy on knowledge and on the use of knowledge in managing the tourist market,

- high level of benefits (tangible and intangible, savings and profits) generated by stakeholders pertains to cooperation with RTO in the broadly understood promotion of members (fairs, web portals, publishing houses, recommendation systems and membership card) as well as participation in the tourist information system, which directly corresponds with the strategic goals of the organization,

- respondents of the survey point to obtaining benefits from cooperation with RTOs in the sphere of their own organizational development, including obtaining additional profits in the joint implementation of tasks in the most economically efficient manner or thanks to the formula of RTO ordering of their own tasks; members or RTO stakeholders from the public sector emphasize their gain in the area of increasing the non-economic aspects of tourism development (increase in tourism migrations and improvement of the image of the tourist destination),

- an interesting observation here should be the indication by stakeholders of the benefits of the pro-tourism investments (mainly obtaining additional funds), although this is not a commonly designated and practically implemented purpose of RTOs - it seems that this area of benefits may be developed by RTOs striving for a market organization model a pro-business organization, although according to the group of experts, this group of benefits is less important for the effectiveness of the organization.

- The summary results of the conducted research indicate that, in the opinion of stakeholders, as many as 25 types of expected benefits from cooperation with RTO are achieved at the level of determined effectiveness threshold (44.64\% of the total 56 types of indicated benefits), and 11 benefits of cooperation with the organization are achieved at the level high-efficiency threshold (19.64\%).

In the light of the above results, the need to modify the structure and characteristics of the RTO operation should be pointed out so that their activities could be decidedly more oriented towards providing clearly identifiable benefits to their members and stakeholders as a guarantee of their organizational effectiveness and development. 
Table 2. Effectiveness of regional tourism organizations from the perspective of the stakeholders achieving benefits from cooperation in their opinion.

\begin{tabular}{|c|c|c|c|c|c|}
\hline \multirow{4}{*}{$\begin{array}{l}\text { The types of stakeholders' benefits identified from cooperation } \\
\text { with regional tourism organizations }\end{array}$} & \multicolumn{5}{|c|}{$\begin{array}{l}\text { Assessment of the effectiveness of regional tourism organizations } \\
\text { from the perspective of the stakeholders achieving benefits from } \\
\text { cooperation with the organization }\end{array}$} \\
\hline & \multicolumn{5}{|c|}{$\begin{array}{c}1 \text { - lack of effectiveness in providing benefits, } 2 \text { - low efficiency } \\
\text { (small benefits), } 3 \text { - I have no opinion as to the level of effectiveness } \\
\text { (benefits achieved), } 4 \text { - actions are effective (I achieve benefits), } \\
5 \text { - high efficiency (I achieve great benefits) }\end{array}$} \\
\hline & 1 & 2 & 3 & 4 & 5 \\
\hline & \multicolumn{5}{|c|}{$\%$ of responses given by respondents } \\
\hline \multicolumn{6}{|l|}{$\begin{array}{l}\text { Area of benefits in the sphere of organization and management } \\
\text { of tourism }\end{array}$} \\
\hline Opportunity to exchange experiences in the undertaken activities & 3.65 & 8.76 & 8.76 & 10.95 & 55.47 \\
\hline $\begin{array}{l}\text { Voluntary cooperation (freedom of joining, leaving the } \\
\text { organization) }\end{array}$ & 0.73 & 2.19 & 2.19 & 17.52 & 54.74 \\
\hline $\begin{array}{l}\text { Formality or informality of cooperation (ordinary, supporting } \\
\text { membership); maintaining the economic and legal independence } \\
\text { of partners (equal passive and active rights) }\end{array}$ & 0.73 & 2.92 & 2.92 & 27.74 & 51.82 \\
\hline $\begin{array}{l}\text { Building a relationship of trust with members of the organization } \\
\text { interested in offering member's own services }\end{array}$ & 5.84 & 6.57 & 6.57 & 23.36 & 49.64 \\
\hline $\begin{array}{l}\text { Creation (extension, consolidation) of the tourism management } \\
\text { system (in the region, Poland) }\end{array}$ & 1.46 & 15.33 & 15.33 & 23.36 & 48.91 \\
\hline $\begin{array}{l}\text { The opportunity to focus various interests, financial resources and } \\
\text { experience of entities in the organization }\end{array}$ & 2.19 & 12.41 & 12.41 & 25.55 & 47.45 \\
\hline $\begin{array}{l}\text { Possibility of accumulation (compliance) of the organization's } \\
\text { goals and own member - benefits for everyone (public, economic } \\
\text { goal - own profit) }\end{array}$ & 2.19 & 8.03 & 8.03 & 29.93 & 47.45 \\
\hline $\begin{array}{l}\text { Involvement of members (acceptance of plans) at the planning } \\
\text { stage, requiring effective implementation of common goals in } \\
\text { practice }\end{array}$ & 1.46 & 10.22 & 10.22 & 28.47 & 47.45 \\
\hline $\begin{array}{l}\text { Allowing each member of the organization to do what they can } \\
\text { best }\end{array}$ & 1.46 & 10.22 & 10.22 & 26.28 & 47.45 \\
\hline $\begin{array}{l}\text { Creation and operation of the structure (division of tasks, powers, } \\
\text { responsibilities) which gives members a sense of being a host }\end{array}$ & 6.57 & 10.95 & 10.95 & 41.61 & 29.20 \\
\hline $\begin{array}{l}\text { Possibilities of coordination of activities in tourism (avoiding } \\
\text { duplication of tasks, projects, structures) }\end{array}$ & 5.11 & 14.60 & 14.60 & 24.09 & 41.61 \\
\hline $\begin{array}{l}\text { Impact as a lobby for authorities (local government, government) } \\
\text { with joint projects, inquiries, interventions }\end{array}$ & 5.84 & 12.41 & 12.41 & 25.55 & 41.61 \\
\hline $\begin{array}{l}\text { Activation through organization activities, remote initiatives and } \\
\text { ideas }\end{array}$ & 4.38 & 11.68 & 11.68 & 32.12 & 40.88 \\
\hline $\begin{array}{l}\text { Consolidation of the potential of people from the region } \\
\text { (their skills, knowledge, experience) for the implementation } \\
\text { of a common tourism strategy }\end{array}$ & 4.38 & 13.14 & 13.14 & 21.90 & 40.15 \\
\hline $\begin{array}{l}\text { Allowing entities that do not operate in tourism to be involved in } \\
\text { the organization }\end{array}$ & 7.30 & 8.03 & 8.03 & 34.31 & 40.15 \\
\hline $\begin{array}{l}\text { The ability to create and function project teams appointed from } \\
\text { members of various organizations }\end{array}$ & 5.11 & 9.49 & 9.49 & 32.85 & 35.77 \\
\hline $\begin{array}{l}\text { Taking responsibility for common concepts - changing attitudes } \\
\text { from claiming members (competing) to active and creative } \\
\text { attitudes }\end{array}$ & 5.11 & 12.41 & 12.41 & 36.50 & 32.12 \\
\hline
\end{tabular}




\begin{tabular}{|c|c|c|c|c|c|}
\hline \multirow{4}{*}{$\begin{array}{l}\text { The types of stakeholders' benefits identified from cooperation } \\
\text { with regional tourism organizations }\end{array}$} & \multicolumn{5}{|c|}{$\begin{array}{l}\text { Assessment of the effectiveness of regional tourism organizations } \\
\text { from the perspective of the stakeholders achieving benefits from } \\
\text { cooperation with the organization }\end{array}$} \\
\hline & \multicolumn{5}{|c|}{$\begin{array}{c}1 \text { - lack of effectiveness in providing benefits, } 2 \text { - low efficiency } \\
\text { (small benefits), } 3 \text { - I have no opinion as to the level of effectiveness } \\
\text { (benefits achieved), } 4 \text { - actions are effective (I achieve benefits), } \\
5 \text { - high efficiency (I achieve great benefits) }\end{array}$} \\
\hline & 1 & 2 & 3 & 4 & 5 \\
\hline & \multicolumn{5}{|c|}{$\%$ of responses given by respondents } \\
\hline \multicolumn{6}{|l|}{ Area of benefits in the financial sphere } \\
\hline $\begin{array}{l}\text { Easier access and more effective fundraising from the EU budget } \\
\text { and funds }\end{array}$ & 8.03 & 8.03 & 8.03 & 24.09 & 42.34 \\
\hline Implementation (co-financing) of joint projects & 9.49 & 4.38 & 4.38 & 27.74 & 41.61 \\
\hline $\begin{array}{l}\text { The possibility of combining public and private resources in } \\
\text { projects }\end{array}$ & 8.03 & 10.95 & 10.95 & 38.69 & 30.66 \\
\hline $\begin{array}{l}\text { Joint (formal partnership) obtaining subsidies for projects } \\
\text { involving resources (institutional, personal) of the organization }\end{array}$ & 7.30 & 10.22 & 10.22 & 32.85 & 37.96 \\
\hline $\begin{array}{l}\text { Substantive support in the creation of grant applications and funds } \\
\text { from EU and budget funds }\end{array}$ & 13.87 & 15.33 & 15.33 & 37.23 & 22.63 \\
\hline $\begin{array}{l}\text { Cooperation (consulting for members and stakeholders) in } \\
\text { obtaining subsidies and funds from EU and budget funds }\end{array}$ & 10.95 & 13.87 & 13.87 & 34.31 & 27.74 \\
\hline \multicolumn{6}{|l|}{ Area of benefits in the area of tourism product development } \\
\hline $\begin{array}{l}\text { Expanding the possibilities of promotion and distribution channels } \\
\text { of the offer and tourist product }\end{array}$ & 2.19 & 3.65 & 3.65 & 13.87 & 53.28 \\
\hline $\begin{array}{l}\text { The possibility to improve the quality of a tourist product (own, } \\
\text { local, regional) }\end{array}$ & 4.38 & 7.30 & 7.30 & 13.14 & 52.55 \\
\hline $\begin{array}{l}\text { A more effective tourist promotion ORT (area of activity } \\
\text { of organizations and members) - increased competitiveness }\end{array}$ & 1.46 & 7.30 & 7.30 & 15.33 & 51.09 \\
\hline $\begin{array}{l}\text { The possibility of creating an attractive tourist offer (own, local, } \\
\text { regional) }\end{array}$ & 5.11 & 4.38 & 4.38 & 13.14 & 49.64 \\
\hline $\begin{array}{l}\text { More effective promotion of tourist offers and products (own, } \\
\text { local, regional) }\end{array}$ & 2.19 & 7.30 & 7.30 & 10.95 & 47.45 \\
\hline $\begin{array}{l}\text { Creating and promoting tourist products in network cooperation } \\
\text { of members (concepts, obtaining subsidies, implementation) }\end{array}$ & 3.65 & 13.87 & 13.87 & 25.55 & 33.58 \\
\hline \multicolumn{6}{|l|}{$\begin{array}{l}\text { The area of benefits in the sphere of research and education } \\
\text { of the protagonist }\end{array}$} \\
\hline $\begin{array}{l}\text { The possibility of organizing joint training on topics of interest } \\
\text { (and developing a similar approach to issues and problems) }\end{array}$ & 5.11 & 11.68 & 11.68 & 25.55 & 44.53 \\
\hline $\begin{array}{l}\text { Possibility to improve qualifications for members and stakeholders } \\
\text { through training }\end{array}$ & 5.84 & 10.95 & 10.95 & 21.90 & 43.80 \\
\hline $\begin{array}{l}\text { The opportunity to attract practitioners from the business (from } \\
\text { the organization) to conduct education and organize specialized } \\
\text { training }\end{array}$ & 8.76 & 11.68 & 11.68 & 27.74 & 38.69 \\
\hline $\begin{array}{l}\text { Cooperation (including paid orders) in tourism research, analyzes, } \\
\text { studies of conditions and tourism strategies }\end{array}$ & 11.68 & 12.41 & 12.41 & 37.96 & 27.01 \\
\hline $\begin{array}{l}\text { Possibility to acquire places for internships and apprenticeships or } \\
\text { in the form of volunteering (potential jobs) }\end{array}$ & 11.68 & 11.68 & 11.68 & 37.96 & 28.47 \\
\hline $\begin{array}{l}\text { Savings on expertise and research (sharing knowledge by } \\
\text { members) }\end{array}$ & 10.22 & 13.87 & 13.87 & 36.50 & 29.20 \\
\hline $\begin{array}{l}\text { Access to specialized data in the field of promotion and tourism } \\
\text { (tourist traffic, brand and image) }\end{array}$ & 4.38 & 17.52 & 17.52 & 24.09 & 35.77 \\
\hline Training support (know-how) in conducting innovative activities & 9.49 & 13.87 & 13.87 & 33.58 & 31.39 \\
\hline $\begin{array}{l}\text { Flow and diffusion of expertise between entities in the } \\
\text { organization }\end{array}$ & 9.49 & 13.87 & 13.87 & 32.85 & 32.12 \\
\hline
\end{tabular}




\begin{tabular}{|c|c|c|c|c|c|}
\hline \multirow{4}{*}{$\begin{array}{l}\text { The types of stakeholders' benefits identified from cooperation } \\
\text { with regional tourism organizations }\end{array}$} & \multicolumn{5}{|c|}{$\begin{array}{l}\text { Assessment of the effectiveness of regional tourism organizations } \\
\text { from the perspective of the stakeholders achieving benefits from } \\
\text { cooperation with the organization }\end{array}$} \\
\hline & \multicolumn{5}{|c|}{$\begin{array}{c}1 \text { - lack of effectiveness in providing benefits, } 2 \text { - low efficiency } \\
\text { (small benefits), } 3 \text { - I have no opinion as to the level of effectiveness } \\
\text { (benefits achieved), } 4 \text { - actions are effective (I achieve benefits), } \\
5 \text { - high efficiency (I achieve great benefits) }\end{array}$} \\
\hline & 1 & 2 & 3 & 4 & 5 \\
\hline & \multicolumn{5}{|c|}{$\%$ of responses given by respondents } \\
\hline \multicolumn{6}{|l|}{$\begin{array}{l}\text { Area of benefits in the sphere of promotion and tourist } \\
\text { information }\end{array}$} \\
\hline $\begin{array}{l}\text { Support in organizing tourist information of its own members or in } \\
\text { the region (info kiosks, internet portals) }\end{array}$ & 2.19 & 6.57 & 6.57 & 15.33 & 48.18 \\
\hline $\begin{array}{l}\text { Preferences (cards, discounts, subsidizing) for members in } \\
\text { statutory activities (events, study trips, publishing houses) }\end{array}$ & 7.30 & 10.22 & 10.22 & 18.98 & 45.99 \\
\hline $\begin{array}{l}\text { Joint publishing projects (reduction of own costs, increasing forms } \\
\text { of promotion for a member) }\end{array}$ & 4.38 & 9.49 & 9.49 & 18.98 & 45.99 \\
\hline $\begin{array}{l}\text { Joint organization of promotional events (offer, tourist product } \\
\text { of a member) - limiting own costs and increasing the forms } \\
\text { of promotion for a member }\end{array}$ & 2.19 & 13.87 & 13.87 & 16.06 & 44.53 \\
\hline $\begin{array}{l}\text { Implementation of joint exhibitions and fairs, B2B / C workshops } \\
\text { bringing additional benefits (tangible, intangible) to a member }\end{array}$ & 0.73 & 511 & 5.11 & 24.09 & 43.80 \\
\hline Providing patronage and recommendations for members & 2.92 & 8.03 & 8.03 & 20.44 & 42.34 \\
\hline $\begin{array}{l}\text { Promotion of members (and stakeholders) on the organization's } \\
\text { website }\end{array}$ & 2.19 & 10.22 & 10.22 & 15.33 & 42.34 \\
\hline Organization of competitions for members and stakeholders & 2.92 & 9.49 & 9.49 & 27.01 & 42.34 \\
\hline $\begin{array}{l}\text { Wide opportunities to promote your attractions (offers, products) } \\
\text { thanks to the involvement of entities in the organization and ROT } \\
\text { capabilities in the PTO-RTO-LTO system }\end{array}$ & 2.19 & 9.49 & 9.49 & 15.33 & 41.61 \\
\hline \multicolumn{6}{|l|}{$\begin{array}{l}\text { Area of benefits in the sphere of own organizational } \\
\text { development }\end{array}$} \\
\hline $\begin{array}{l}\text { Increasing non-economic aspects of tourism development (increase } \\
\text { of traffic, improvement of the image of the destination) }\end{array}$ & 5.11 & 9.49 & 9.49 & 24.09 & 46.72 \\
\hline $\begin{array}{l}\text { Implementation of tasks in the most economically efficient way } \\
\text { (profits) }\end{array}$ & 8.76 & 11.68 & 11.68 & 46.72 & 26.28 \\
\hline $\begin{array}{l}\text { It is possible to order a part of own tasks for RTO, because it may } \\
\text { be easier to implement them (get additional funds, limit tenders) }\end{array}$ & 12.41 & 14.60 & 14.60 & 41.61 & 21.90 \\
\hline Providing services to solve local tourism problems & 10.95 & 15.33 & 15.33 & 40.15 & 24.82 \\
\hline $\begin{array}{l}\text { Possibility of social (public) acceptance for the organization's } \\
\text { activities (including its own members) }\end{array}$ & 5.84 & 10.95 & 10.95 & 32.12 & 38.69 \\
\hline \multicolumn{6}{|l|}{ Area of benefits in the sphere of the proto-investment } \\
\hline $\begin{array}{l}\text { Effective distribution of investment risk (increasing the ability to } \\
\text { accept higher risk) }\end{array}$ & 17.52 & 7.30 & 7.30 & 58.39 & 10.22 \\
\hline $\begin{array}{l}\text { Possibility to start investment in PPP with members which allows } \\
\text { you to raise more funds and increase the scope of work }\end{array}$ & 16.06 & 8.03 & 8.03 & 53.28 & 16.79 \\
\hline $\begin{array}{l}\text { The possibility of attracting private investors to carry out } \\
\text { investment own tasks (RTO, a control platform for ventures, may } \\
\text { create non-commercial SPVs) }\end{array}$ & 20.44 & 8.03 & 8.03 & 51.82 & 14.60 \\
\hline $\begin{array}{l}\text { The possibility of obtaining funds that a member cannot access } \\
\text { on their own (loans for special purpose vehicles, venture capital, } \\
\text { green-fields and subsidies for non-governmental / non-profit } \\
\text { organizations) }\end{array}$ & 21.17 & 9.49 & 9.49 & 51.82 & 11.68 \\
\hline
\end{tabular}

Source: own study based on surveys. 
Analysis of the developed profiles of the effectiveness of the implementation of statutory objectives (regarding the construction of a cooperation network) by the examined RTOs (see: Fedyk, 2016) from the perspective of the organization's stakeholders assessment allows to formulate the following conclusions:

- there are very strong disproportions in the effectiveness of achieving the objectives for building a network of cooperation with the environment (included in the organization's statutes) from the almost full effectiveness of achieving them (ROTWŁ, SOT) through effectively implementing only selected objectives (PDROT, WOT), to the lack of effectiveness in this range (DOT, KPOT, LROT); ${ }^{4}$ what is important for the system is the fact that cooperation with LOT is achieved by all surveyed organizations with a minimum level of effectiveness (apart from DOT - lack of effectiveness),

- the fact of low (or complete lack of) effectiveness of RTOs in the field of achieving objectives serving the development, strengthening and boosting cooperation networks with the environment and postulated by authors (including experts in the study) based on literature studies, as only individual goals are efficiently reached, should be considered worrying. They are effectively achieved only by PDROT (4), ŚOT (3), WOT (3), LROT (2) and ZROT (1), and a high level of effectiveness was achieved in this area only by ROTWŁ (9 goals out of 13 indicated).

At the same time, a visible picture of the effectiveness of the implementation of statutory objectives (including building cooperation relations) by the examined RTOs confirms the original thesis about the strong impact of the environment (stakeholders) on perceiving the effectiveness of these organizations, and highlights the strong impact of regional conditions in the operation of RTOs, which in their statutes, they try to adapt (sometimes "forcefully") to the local conditions of management of tourist promotion or the rules of obtaining funds.

The analysis of the performance profiles of the surveyed RTOs from the perspective of achieving by stakeholders the benefits of cooperation allows to formulate the following conclusions:

- strong disproportions in the level of effectiveness of benefits achieved by RTO stakeholders have been found, which is indicated, inter alia, by the number of those benefits at the level of the determined effectiveness threshold ranging from 1 (KPOT) to 38 (DOT) and the number of benefits achieved at the high level of effectiveness ranging from 0 (KPOT, LROT, ZROT) to 38 (ROTWŁ),

- there is a noticeable convergence in reaching by stakeholders of several RTOs similar benefits at a similar level of effectiveness in the sphere of organization and management

4 ROTWŁ - Regionalna Organizacja Turystyczna Województwa Łódzkiego [Regional Tourism Organization of Łódzkie Voivodship], ŚOT - Śląska Organizacja Turystyczna [Silesian Tourism Organization], PDROT-Podkarpacka Regionalna Organizacja Turystyczna [Subcarpathian Regional Tourism Organization], WOT - Wielkopolska Organizacja Turystyczna [Tourism Organization of Greater Poland], DOT - Dolnośląska Organizacja Turystyczna [Tourism Organization of Lower Silesia], KPOT - Kujawsko-Pomorska Organizacja Turystyczna [Tourism Organization of Kujawy and Pomorze], LROT - Lubelska Regionalna Organizacja Turystyczna [Regional Tourism Organization of Lublin].

5 ZROT - Zachodniopomorska Regionalna Organizacja Turystyczna [Regional Tourism Organization of Western Pomerania]. 
of tourism (ROTWŁ, DOT, ŚOT - high efficiency and large profits, WOT, PDROT - activities are effective and I achieve benefits); in the analogous system, there are small benefits (LROT, ZROT) or almost none (KPOT),

- in the group of benefits of a financial nature there are strong disproportions between RTOs (effectiveness thresholds achieved by ROTWŁ, PDROT, WOT, DOT), and low efficiency (ZROT, LROT) or its lack in ŚOT and KPOT,

- clear similarities were found between RTOs in terms of the degree of obtaining the same benefits in the area of tourism product development (ROTWL, SWOT and WOT stakeholders benefit greatly, DOT, LROT, PDROT and ZROT stakeholders benefit, and their lack is indicated by the stakeholders of the KPOT),

- strong disproportions between RTOs were found in relation to the degree of obtained benefits related to the access to research (tourist market analysis) and pro-tourist education (specialist training) - big benefits (high-efficiency threshold) are achieved by ROTW stakeholders, the (threshold) benefits are obtained by PDROT stakeholders, and to a small extent also stakeholders of DOT, SOT and LROT, lack of benefits (ineffectiveness) is characterized by KPOT and ZROT,

- there is a convergence in the achievement of similar benefits (material and immaterial) of similar RTOs to the similar level of effectiveness in the promotion of members (trade fairs, web portals, publishing houses, recommendation systems and membership card) and participation in the tourist information system (high thresholds). Effectiveness achieved in ROTWŁ, efficacy thresholds obtained in DOT, LROT, PDROT, WOT, ZROT, and lack of effectiveness (benefits) noted in the KPOT,

- stakeholders of most RTOs indicate a low level of benefits obtained from cooperation with RTOs in the sphere of their own organizational development, including those related to the level of additional profits obtained when jointly performing tasks in an economically efficient manner or thanks to the own RTO task allocation formula (lack of effectiveness in KPOT, ŚST and ZROT, very low effectiveness in LROT, WOT, PDROT, and thresholds of effectiveness for selected traits achieved only in DOT and ROTWŁ),

- an interesting observation should be the indication by stakeholders of almost all RTOs (except for DOT and ROTW $Ł$ ) on the lack of achieving any benefits in the area of pro-tourist investments (mainly referring to the possibility of obtaining additional financial resources through cooperation).

The analysis of the levels of effectiveness of the stakeholders achieving benefits from cooperation with the RTOs allows for indicating a strong "deviation" of RTOs in many areas in relation to the postulated pattern of effectiveness profile of this variable based on the opinions of experts participating in the survey. Experts indicated as many as 38 types of benefits $(67.85 \%$ out of the 56 identified by the authors), which in their opinion should be guaranteed and effectively achieved by the organization, and are not obtained in the expected range and at the required level in most RTOs (specific exception here is ROTWŁ). 
The analysis indicates and authorizes the existence of the phenomenon of strong criticism among RTO stakeholders that results in the opinion about the extremely low effectiveness of the organization (KPOT) or extremely favorable opinions (ROTWŁ) indicating high efficiency of the organization. The results of the comparative research of the profiles of the effectiveness of benefits of RTO stakeholders are also a proof of the need to develop levels and areas of cooperation with members of the organization as well as intensify communication with the environment in order to present the achievements of the organization with which its members can identify and thus also recognize them for fulfilling their own expectations.

\section{Model of RTO functioning}

On the basis of literature studies, own analyzes and results, diagnostic surveys and own long-term observations of the three-tier management system for tourism promotion in Poland (in particular regional tourism organizations), the article presents the original model of RTOs functioning as a network cooperation organization (fig. 2, tab. 3), which after implementation to the organizational practice can provide a fundamental and perfect change and increase the effectiveness of the organization (Fedyk 2016; Fedyk, Morawski, 2016; Fedyk, Kachniewska, 2016) and, consequently, a more effective promotion of the tourist region.

The proposed model (tab. 4) assumes achieving certain types of parameters of the RTO functioning efficiency assigned to the performance of particular roles by the organization and relating to the effectiveness of achieving statutory objectives (51 variables), effectiveness of economic objectives (30 variables), effectiveness of achieving benefits from cooperation with RTO by stakeholders (56 variables) and general efficacy traits (60 variables). 


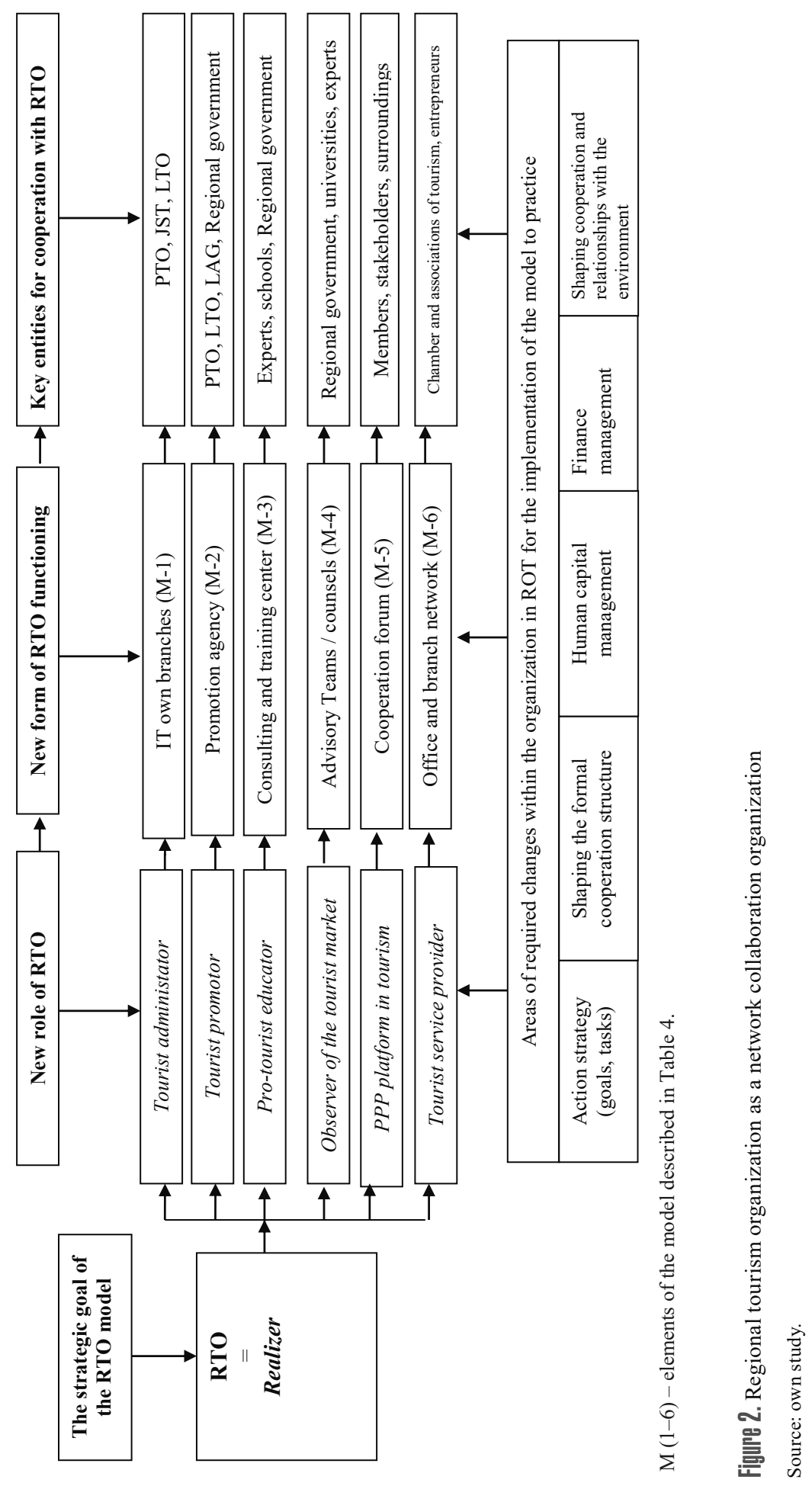


Table 3. Regional tourism organization as an organization of network cooperation description of selected operating features and implementation conditions

\begin{tabular}{|c|c|c|}
\hline $\begin{array}{l}\text { Element of the model } \\
\text { (role of RTO) }\end{array}$ & Features, activities, special tasks of RTO & $\begin{array}{c}\text { Determinants of implementation to } \\
\text { organizational practice in RTO }\end{array}$ \\
\hline $\begin{array}{l}\text { Tourist administrator } \\
\text { M-1 }\end{array}$ & $\begin{array}{l}\text { RTO fulfills the function of the tourist information system } \\
\text { administrator in the region by consolidating tourist } \\
\text { information points (IT databases) (common databases, } \\
\text { uniform data classification system, periodic training } \\
\text { for employees of IT points) and their certification (in } \\
\text { cooperation with PTO, LTO and local government units), } \\
\text { - } \text { it is possible to create their own IT point in cooperation } \\
\text { with the voivodship self-government, large urban } \\
\text { agglomerations and tourist chambers and entities } \\
\text { operating in communication services for tourists (airports, } \\
\text { railway and bus stations) - commercialization of some } \\
\text { of the services provided at the IT point, i.e. intermediation } \\
\text { in the booking of foreign services, advertising and } \\
\text { promotional services for non-members of the organization }\end{array}$ & $\begin{array}{l}\text { undertaking lobbying and substantive } \\
\text { activities to integrate the network } \\
\text { of IT points (including the development } \\
\text { of a specialized concept, obtaining } \\
\text { a special purpose subsidy from budgetary } \\
\text { funds - Ministry of Sport and Tourism } \\
\text { or EU funds - Regional Operational } \\
\text { Program, PO Intelligent Development, } \\
\text { conducting specialized training for IT staff } \\
\text { in the region, full implementation of IT } \\
\text { certification in agreement with LTO, local } \\
\text { government units (JST) according to the } \\
\text { PTO model), } \\
\text { adoption of relevant resolutions by the } \\
\text { management board of RTO regarding } \\
\text { creation of own IT point (obtaining } \\
\text { the place and subsidies for its launch } \\
\text { in consultation with interested parties, } \\
\text { creating a catalog of information } \\
\text { and promotion services for their } \\
\text { commercialization, setting the rules for the } \\
\text { promotion of organization members by } \\
\text { the IT point, providing specialist trained } \\
\text { personnel the point can also be run in the } \\
\text { form of entrusting a task to a given LTO), } \\
\text { formal and legal regulation of conducting } \\
\text { business activity by RTO (registration } \\
\text { in the National Court Register (KRS), } \\
\text { introduction of accounting and accounting } \\
\text { required by law) }\end{array}$ \\
\hline $\begin{array}{l}\text { Tourist promotor } \\
\text { M-2 }\end{array}$ & $\begin{array}{l}\text { undertaking activities and initiatives aimed at appointing } \\
\text { at RTO, the so-called Partner Groups (GP) with a wide } \\
\text { participation of tourist entrepreneurs (also from LAGs, } \\
\text { including representatives of ordinary members) aimed at } \\
\text { creating network tourism products in the region and the } \\
\text { target transformation of the GP into LTOs, } \\
\text { - launching and administering a specialized internet } \\
\text { portal with a semantic search engine for regional tourist } \\
\text { products (ultimately also commercialization through } \\
\text { online booking and purchasing) and promoting certified } \\
\text { tourist products, } \\
\text { cyclical edition in cooperation with entrepreneurs and } \\
\text { representatives of attractions of electronic catalogs } \\
\text { of regional tourist products and their extensive } \\
\text { redistribution through new ITC channels in tourism: } \\
\text { mobile applications, thematic blogs, social networks }\end{array}$ & $\begin{array}{l}\text { creating a concept for the operation } \\
\text { of partner groups and a wide dissemination } \\
\text { of the idea (conferences, workshops and } \\
\text { presentations in the region, publication } \\
\text { of an instruction-guide, specialist training } \\
\text { for future leaders of partner groups), } \\
\text { - } \text { creating rules for acquiring tourist products } \\
\text { for implementation to the portal (including } \\
\text { unification of the form of their presentation, } \\
\text { conclusion of contracts for brokering sales, } \\
\text { activities promoting a portal), } \\
\text { creating a substantive, graphic and } \\
\text { technical concept of a regional catalog } \\
\text { of tourist products (obtaining subsidies } \\
\text { for implementation and a distribution } \\
\text { system from budget funds - MSiT or EU } \\
\text { funds - Regional Operational Program, } \\
\text { PO Intelligent Development, starting } \\
\text { cooperation with IT points in the field } \\
\text { of dissemination and promotion of the } \\
\text { catalog) }\end{array}$ \\
\hline
\end{tabular}




\begin{tabular}{|c|c|c|}
\hline $\begin{array}{l}\text { Pro-tourism educator } \\
\text { M-3 }\end{array}$ & $\begin{array}{l}\text { - establishment with RTO of a professional personnel } \\
\text { training center (ORK) for tourism in cooperation with } \\
\text { territorial self-government units (targeted measures, } \\
\text { EU subsidy) and with the participation of experts } \\
\text { from universities and the tourism sector (e.g., tourism } \\
\text { chambers, hotel associations, tour operators of inbound } \\
\text { tourism) - including those obtained from representatives } \\
\text { of ordinary members, } \\
\text { - } \text { organization within ORK free or under preferential } \\
\text { terms of specialist training for organization members } \\
\text { (e.g. tourist information, tourism management, promotion } \\
\text { and advertising, modern technologies, innovation in } \\
\text { tourism, creating applications for subsidies from EU } \\
\text { funds and budget funds), } \\
\text { organization of thematic trainings within ORK services } \\
\text { with pro-profession entitlements (e.g. tourist informer } \\
\text { I-III class, IT center manager, tourist product animator, } \\
\text { leader of local action groups and local tourism } \\
\text { organizations, specialist for trade fairs and tourist } \\
\text { publications in a local government unit), } \\
\text { organization of several permanent and thematic advisory } \\
\text { teams at RTO, providing consultancy services (free } \\
\text { of charge for members, and commercially for entities } \\
\text { from the environment) - members of teams acquired, } \\
\text { among others, from representatives of ordinary members }\end{array}$ & $\begin{array}{l}\text { - adoption of relevant resolutions by the } \\
\text { management board of RTO regarding } \\
\text { appointing the ORK (acquisition of subsidy, } \\
\text { facility),formal and legal regulation } \\
\text { of conducting business activity by RTO } \\
\text { (registration in the National Court Register, } \\
\text { introduction of accounting and accounting } \\
\text { required by law), } \\
\text { - lobbying and conclusion of agreements } \\
\text { (long-term civil law agreements) with local } \\
\text { governments in the scope of establishing } \\
\text { ORK, } \\
\text { - creation of a thematic training system } \\
\text { (acquisition of lecturers, development } \\
\text { of programs, creation of a promotion and } \\
\text { recruitment system, rental of an object with } \\
\text { training infrastructure - ultimately own } \\
\text { facility), } \\
\text { adoption of appropriate resolutions by } \\
\text { the management board of RTO regarding } \\
\text { appointing advisory teams (obtaining } \\
\text { experts, providing financial resources as } \\
\text { a part of the annual plan, creating a catalog } \\
\text { of commercial consultancy services) }\end{array}$ \\
\hline $\begin{array}{l}\text { Observer of the tourist } \\
\text { market } \\
\text { M-4 }\end{array}$ & $\begin{array}{l}\text { - } \text { establishment of a permanent team for tourist market } \\
\text { research in the structure of the RTO office (office staff, } \\
\text { experts, academics, representatives of the voivodship } \\
\text { self-government - including those obtained from } \\
\text { representatives of ordinary members), } \\
\text { - } \\
\text { sharing your results or analyzes (own or acquired from } \\
\text { MSiT, PTO, from other entities of the tourist economy or } \\
\text { monitoring the Internet network) concerning the tourism } \\
\text { market using modern technologies (e.g. specialist tab } \\
\text { on the website, specialist newsletter) - data provided } \\
\text { free of charge to members organization and their } \\
\text { commercialization towards other interested entities }\end{array}$ & 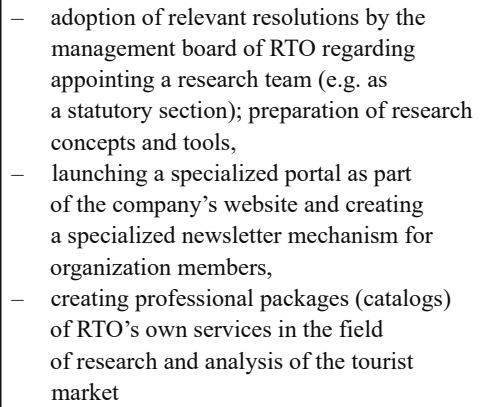 \\
\hline
\end{tabular}




\begin{tabular}{|c|c|c|}
\hline $\begin{array}{l}\text { PPP platform in tourism } \\
\text { M-5 }\end{array}$ & 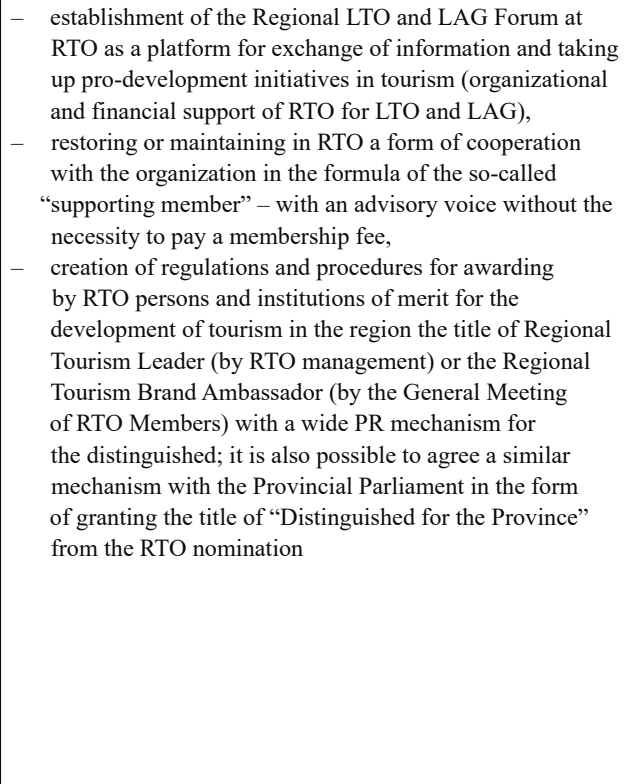 & $\begin{array}{l}\text { - adoption of relevant resolutions by } \\
\text { the management board of RTO for } \\
\text { implementation of the forum and lobbying } \\
\text { activities to establish cooperation with } \\
\text { LTO and LAG; entering the project into the } \\
\text { annual ROT plan and financial plan, } \\
\text { - formal and legal regulation in the } \\
\text { RTO statute of the issue of supporting } \\
\text { membership with the specification of a new } \\
\text { catalog of rights and obligations; lobbying } \\
\text { activities aimed at acquiring supporting } \\
\text { members, especially from the sphere } \\
\text { of tourist entrepreneurship and from } \\
\text { outside the tourism sector, } \\
\text { development of rules and regulations for } \\
\text { granting special distinctions to meritorious } \\
\text { persons and their approval by resolutions } \\
\text { of the management board and the General } \\
\text { Meeting of Members; a wide promotional } \\
\text { campaign disseminating the idea and } \\
\text { promoting the distinguished (ultimately } \\
\text { creating a special tab in the company's } \\
\text { web portal); developing a statuette in the } \\
\text { competition mode for people distinguished } \\
\text { as a symbol associated with the region }\end{array}$ \\
\hline $\begin{array}{l}\text { Tourist service provider } \\
\text { M-6 }\end{array}$ & 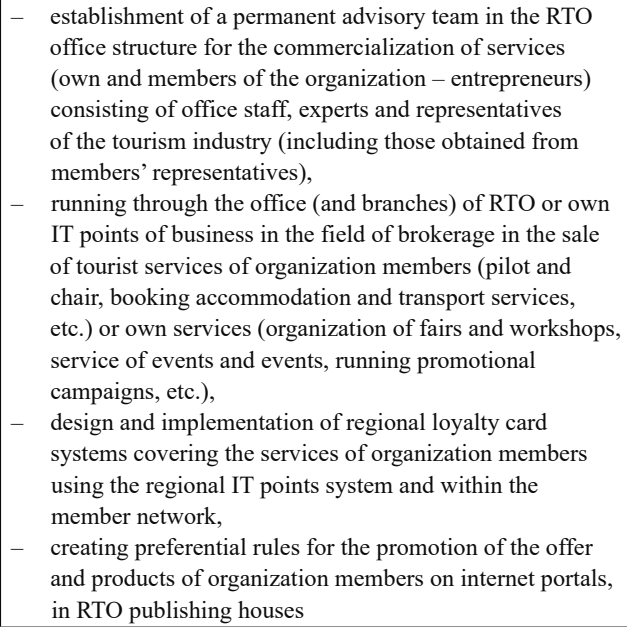 & 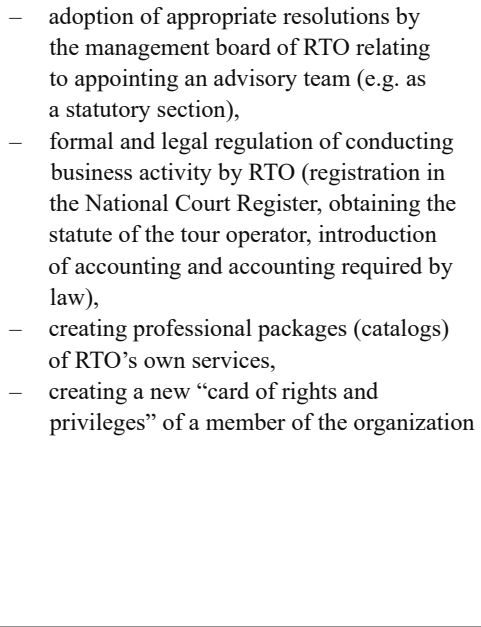 \\
\hline
\end{tabular}

Source: own elaboration. 
Table 4. The forecasted effectiveness of the model of functioning of regional tourism organization as a network cooperation organization.

\begin{tabular}{|c|c|c|c|c|c|}
\hline \multicolumn{2}{|c|}{ Role of RTO according to the model } \\
\hline $\begin{array}{c}\text { Tourist administrator } \\
\text { M-1 }\end{array}$ & $\begin{array}{c}\text { Tourist promotor } \\
\text { M-2 }\end{array}$ & $\begin{array}{c}\text { Pro-tourism educator } \\
\text { M-3 }\end{array}$ & $\begin{array}{c}\text { Observer of the tourist } \\
\text { market } \\
\text { M-4 }\end{array}$ & $\begin{array}{c}\text { PPP platform in } \\
\text { tourism } \\
\text { M-5 }\end{array}$ & $\begin{array}{c}\text { Tourist service } \\
\text { provider } \\
\text { M-6 }\end{array}$ \\
\hline \multicolumn{5}{|c|}{$\begin{array}{c}\text { Forecast achievement of parameters for the effectiveness of the RTO operation } \\
\text { (with a minimum threshold value in the expert profile for RTO) }\end{array}$} \\
\hline Statutory aims & Economic aims & Stakeholders' benefits & $\begin{array}{c}\text { Effectiveness } \\
\text { characteristics }\end{array}$ \\
\hline 14 & 8 & 26 & 16 \\
\hline
\end{tabular}

Source: own elaboration based on Fedyk (2016).

In the adopted concept of the proposed model of effective operation of RTO, as a network collaboration organization, the essential features are as follows:

- flexibility which allows for using all elements of the model or only its selected elements (here - choosing the role to be performed by RTOs or organizational and legal forms ${ }^{6}$ ) and at the same time each of these selected parts together or separately bring with it an increase in the effectiveness of the organization after its implementation to organizational practice,

- the possibility of evolutionary and non-revolutionary organizational changes with the use of the proposed model, while at the same time being free to determine the intensity and period of implementation of these changes,

- founding new RTO rules contained in the model on multidirectional cooperation with their members and stakeholders in a turbulent environment, while simultaneously adapting to the contemporary conditions of a competitive knowledge-based economy and managed by knowledge,

- the possibility of building, after the implementation of the model for organizational practice, a new type of organization - the transition to a synergistic organization open to searching for various connections of elements of its own way of acting with elements of other ways,

- the possibility of building new platforms and activating the cooperation of a larger number of members and stakeholders, with the reservation of an individual RTO decision regarding the choice of the final legal basis for the operation of a given form,

- the ability to build, based on the role of RTO and model features, a new structure of strategic goals of the organization's operation, and further the system of related operational goals (including tasks),

- providing an opportunity to enable the operation of a given RTO in its most favorable formula: cooperation (when goals and strategies of members are similar), coopetition (when goals of members are different and their strategies are similar) or complementarity (when goals of members are similar and their strategies are different),

6 In determining new roles for RTO, the concept indicated by Zmyślony (2014) was also used. 
- the possibility of monitoring and assessing the effectiveness of the RTO in a new model based on the use of specific performance indicators,

- lack of formal and legal obstacles for RTOs currently operating as an association, to implement the model to organizational practice, subject to possible minor corrections or additions to statutory documents of the organization and to conduct an adequate change in the accounting and bookkeeping system in the organization.

The key determinants (limitations) when implementing the proposed model for the RTO practice are:

- the necessity of basic intra-organizational adjustments in the field of financial management (relocation of funds, diversification of sources, development or launching of a business and commercialization of own services),

- correction of the human resources management system (general reinforcement of human resources at the RTO office),

- correction of decision mechanisms by statutory bodies (management) of RTOs (strengthening of the process of socialization of decisions by the system and forms of advice with the participation of members and stakeholders).

\section{References}

Act of June 25, 1999 on Polish Tourism Organization. Journal of Laws no. 62, item 689, as amended.

Borzyszkowski, J. (2011a). Organizacja i zarządzanie turystyka w Polsce. Warsaw: CeDeWu.

Borzyszkowski, J. (2011b). Regionalne organizacje turystyczne w Polsce na tle rozwiązań w wybranych krajach. In: A. Rapacz (ed.), Gospodarka turystyczna w regionie. Przedsiębiorstwo. Samorząd. Wspótpraca (375-387).

Bratnicki, M. (2009). Pomiar efektywności organizacji świadczących usługi publiczne. In: A. Frączkiewicz-Wronka (ed.), Zarzadzanie publiczne - elementy teorii i praktyki (pp. 80-105). Katowice: Uniwersytet Ekonomiczny w Katowicach.

Cameron, K.S., Quinn, R.E. (1983). Organizational Life Cycles and Shifting Criteria of Effectiveness: Some Preliminary Evidence. Management Science, 1, 33-51.

Czernek, K. (2012). Trendy w popycie turystycznym jako determinanty współpracy w regionie. Zeszyty Naukowe Uniwersytetu Szczecińskiego, 697. Ekonomiczne Problemy Ustug, 82, 69-80.

Dębski, M. (2012a). Współpraca interesariuszy destynacji w procesie kreowania jej konkurencyjności. Organizacja i Kierowanie, 3 (152), 73-86.

Dębski M. (2012b). Marketing we współczesnym przedsiębiorstwie. Przedsiębiorczość i Zarządzanie, 2 (13), 45-65.

Fedyk, W. (2016). Uwarunkowania skuteczności regionalnych organizacji turystycznych w Polsce. Doctoral thesis. Jelenia Góra: Uniwersytet Ekonomiczny we Wrocławiu (unpublished).

Fedyk, W., Kachniewska, M. (2016). Uwarunkowania skuteczności funkcjonowania regionalnych organizacji turystycznych w Polsce w formule klastra. Ekonomiczne Problemy Turystyki, 1 (33), 135-150.

Fedyk, W., Morawski, M. (2014). Regionalne organizacje turystyczne - organizacjami współpracy. Prawda czy fałsz? Folia Turistica, 32, 241-274.

Fedyk, W., Morawski, M. (2016). Uwarunkowania skuteczności funkcjonowania regionalnych organizacji turystycznych w obszarach recepcji turystycznej w Polsce. Ekonomiczne Problemy Turystyki, 1 (33), 107-124.

Fedyk, W., Meyer, B., Potocki, J. (2017). Nowa koncepcja zarządzania regionami turystycznymi. Studia Oeconomia Posnaniensia, 4 (4), 50-81. 
Gołembski, G., Niezgoda, A. (2014). Organization of Tourism in Poland after Twenty Years of Systematic Changes. In: C. Costa, E. Panyik, D. Buhalis (eds.), European Tourism Planning and Organisation Systems: The EU Member States (pp. 243-256). Bristol: Channel View Publications.

Grabińska, E., Mierniczak, P. (2010). Rola i znaczenie regionalnych organizacji turystycznych w zakresie promocji turystycznej regionu. In: J. Sala (ed.), Konkurencyjność miast i regionów na globalnym rynku turystycznym (pp. 613-636). Warsaw: Wydawnictwo Naukowe PWN.

Greiner, L.E. (1972), Evolution and Revolution as Organizations Grow. Harvard Business Review, 4 (50).

Griffin, R.W. (2004). Podstawy zarzadzania organizacjami. Warsaw: Wydawnictwo Naukowe PWN.

Kowal, W. (2013). Skuteczność i efektywność - zróżnicowane aspekty interpretacji. Organizacja i Kierowanie, 4 (157), $11-22$.

Migdal, M. (2008), Ewaluacja regionalnych i lokalnych organizacji turystycznych. Szczecin: Instytut Wspierania Turystyki - Doradztwo, Szkolenia, Badania, Forum Turystyki Regionów.

Morawski, M. (2012). Uwarunkowania dzielenia się wiedzą z udziałem pracowników kluczowych. Wnioski z badań. In: M. Morawski (ed.), Zarządzanie wiedza w turystyce a efektywność gospodarki turystycznej (pp. 45-60). Wrocław: Akademia Wychowania Fizycznego.

Olearnik, J. (2009). Przedsiębiorcze zachowania uczelni - wzorzec i rzeczywistość (wyniki badań). In: M. Pluta-Olearnik (ed.), Przedsiębiorcza uczelnia i jej relacje z otoczeniem (pp. 49-87). Wrocław: Difin, Wyższa Szkoła Handlowa we Wrocławiu.

Panasiuk, A. (2009). Instrumenty polityki turystycznej w regionie. In: A. Rapacz (ed.), Gospodarka turystyczna w regionie. Przedsiębiorstwo. Samorząd. Wspótpraca. (pp. 15-23). Wrocław: Uniwersytet Ekonomiczny we Wrocławiu.

Rapacz, A., Jaremen, D. (2007). Regionalne organizacje turystyczne, jako przejaw partnerstwa w gospodarce turystycznej. Przypadek Dolnego Śląska. In: A. Rapacz (ed.), Gospodarka turystyczna w regionie. Wybrane zagadnienia jej funkcjonowania (pp. 222-233). Jelenia Góra: Jaremen Press.

Opracowanie metody oceny efektywności działań ROT i przeprowadzenie badań pilotażowych w dwóch województwach w celu zweryfikowania narzędzi oceny". Warsaw: SMG/KRC Poland Media na zlecenie Ministerstwa Sportu i Turystyki, 10 December 2008.

Sobolewski, K. (1998). O pojęciu skuteczności i pojęciach związanych. Koszalin: Wydawnictwo Politechniki Koszalińskiej.

Stabryła, A. (2011). Problemy doskonalenia i rozwoju struktur organizacyjnych. Nauki o Zarządzaniu, 8 (216), 20-31.

Walas, B. (2007). Kierunki ewolucji regionalnych i lokalnych organizacji turystycznych w kontekście polityki turystycznej - mocne i słabe strony. Rocznik Naukowy Wyższej Szkoły Turystyki i Rekreacji im. M. Orłowicza w Warszawie, $6,1-10$.

Wanagos, M. (2011). Regionalne i lokalne organizacje turystyczne - system relacji i powiązań marketingu wewnętrznego regionu. Zeszyty Naukowe Uniwersytetu Szczecińskiego, 663. Ekonomiczne Problemu Usług, 75, 284-285.

Waterman, R., Peters, T. (1986). W poszukiwaniu doskonałości w biznesie, cz. IV: System wartości. Wektory, 11-12, $39-43$.

Wąsowicz-Zaborek, E. (ed.) (2009). Kodeks Dobrych Praktyk systemu zarzadzania i promocji turystyki w Polsce. Warsaw: Polska Organizacji Turystyczna.

Weiermair, K. (1997). On the concept and definition of Quality in Tourism. St. Gallen: AIEST.

Zieleniewski, J. (1972). Organizacja zespołów ludzkich. Wstęp do organizacji i kierowania, Warsaw: Polskie Wydawnictwo Naukowe.

Ziębicki, B. (2012). Metodyka oceny efektywności organizacyjnej. In: B. Mikuła (ed.), Historia i perspektywy nauk o zarządzaniu (pp. 381-391). Cracow: Wydawnictwo Fundacji Uniwersytetu Ekonomicznego w Krakowie.

Zmyślony, P. (2013). Konieczne korekty systemu, Aktualności Turystyczne. Retrieved from: http://www.aktualnosciturystyczne.pl/wiadomoci-rot-i-lot/konieczne-korekty-systemu (8.12.2013).

Zmyślony, P. (2014). Realizator, partner czy przywódca - funkcje i relacje. MODEL wspólpracy JST - ROT - LOT $L G D$, VII Gremium Ekspertów Turystyki, 10-12.12.2014r. Kraków-Sucha Beskidzka. Retrieved from: http:// 
turystykawmiescie.org/2014/12/12/realizator-partner-czy-przywodca-o-modelu-wspolpracy-jst-rot-lot-lgd-relacja/ (14.12.2014).

Żemła, M. (2010). Możliwości i ograniczenia pełnienia roli przywódcy w kooperacyjnym kreowaniu potencjału turystycznego obszaru recepcji przez lokalne i regionalne organizacje turystyczne. Zeszyty Naukowe Uniwersytetu Szczecińskiego, 591. Ekonomiczne problemy ustug, 53, 93-102.

\section{MODEL WSPÓŁPRACY W SIECI ORGANIZACJI NIEBĘDĄCYCH PRZEDSIĘBIORSTWAMI NA PRZYKŁADZIE REGIONALNYCH ORGANIZACJI TURYSTYCZNYCH W POLSCE}

SŁOWA KLUCZOWE STRESZCZENIE regionalne organizacje turystyczne, skuteczność, modele współpracy, zarządzanie promocją

Zdaniem autorów, w obliczu radykalnych zmian w turystyce, a z drugiej osiągniętego wysokiego poziomu dojrzałości organizacyjnej, w tym poziomu kompetencji merytorycznych należy szukać nowej misji dla regionalnych organizacji turystycznych (ROT-ów). Problem badawczy należałoby zatem zdefiniować jako ustalenie jaki model funkcjonowania (współpracy) ROT-ów jest adekwatny względem uwarunkowań wewnętrznych i zewnętrznych oraz cech działania wpływających na możliwość skutecznego funkcjonowania organizacji. Celem opracowania jest sformułowanie propozycji nowego modelu funkcjonowania ROT-ów opartego na sieciowej organizacji współpracy z interesariuszami. W pracy wykorzystano spójny i zarazem wszechstronny zbiór metod badawczych ilościowo-jakościowych, w tym wielowymiarowy, autorski sondaż diagnostyczny i wieloetapową i nowatorską metodę oceny skuteczności działania ROT-ów.

Autorzy wyznaczają i wartościują katalog cech wpływających na poziom skuteczności funkcjonowania ROT-ów, a odnoszących się do charakteru współpracy organizacji z jej otoczeniem. Pomimo ujawnionych rozbieżności poglądów na temat kierunków i celowości modyfikacji systemu regionalnych organizacji turystycznych, autorzy proponują ewolucyjny model funkcjonowania ROT w formule sieciowej organizacji współpracy, wskazując cechy, działania i zadania pozwalające na wdrożenie tego modelu do praktyki organizacyjnej, a w konsekwencji służące wzrostowi skuteczności działania organizacji, a dalej implikujące zmiany w logistyce i jakości zarządzania promocją turystyczną regionu. W opinii autorów przyjęta metoda badania skuteczności ROT-ów w sferze współpracy sieciowej z interesariuszami powinna być implementowana do praktyki oceny skuteczności działania innych organizacji nie będących przedsiębiorstwami, a działających w sferze zarządzania i promocji turystyki. 